\title{
NUTRITIONAL AND MICROBIOLOGICAL COMPONENTS OF HONEY SAMPLES OBTAINED FROM OGUN STATE, SOUTHWESTERN NIGERIA.
}

\author{
By
}

\author{
${ }^{1}$ M. O. ADENEKAN, N. A. AMUSA ${ }^{2}$, V. E. OKPEZE ${ }^{1}$ and A. O. OWOSIBO ${ }^{3}$
}

\begin{abstract}
There are no detailed studies on the nutritional and microbiological characteristics of honey produced in Ogun State in the Southwestern part of Nigeria. This paper investigated these components in honeys produced from different parts of this state. A total of 10 honey samples per year were collected for the years 2008 - 2010. These were separately analyzed for their physical properties, nutritional and microbiological components in the laboratory. The results of the physical properties showed that honey samples obtained from Ago-Iwoye has the lowest $\mathrm{pH}$ of 3.48, which was significantly different from the $\mathrm{pH}$ values of 5.06, 5.21 and 4.06 obtained from honey samples from Abeokuta, Ibefun and Ilisan honey samples respectively. There was significant difference in moisture contents of honey samples obtained from Ogere (16.19\%), Otta $(19.14 \%)$ and Ijebu-Ode $(18.21 \%)$, while the percentage ash contents of $0.78 \%$ obtained from honey samples collected from Abeokuta was not significantly different from the value of $0.75 \%$ obtained from Ago-Iwoye honey $(\mathrm{P} \leq 0.05)$. However, the value of $1.11 \mathrm{mg} 100 \mathrm{~g}^{-1}$ for hydroxymethylfurfural obtained from Ago-Iwoye honey samples was not significantly different from the value of $0.32 \mathrm{mg} 100 \mathrm{~g}^{-1}$ in honey samples obtained from Sagamu.

The value for glucose ranged from $18.42-30.16 \mathrm{~g} 100 \mathrm{~g}^{-1}$, while fructose sugar varied between

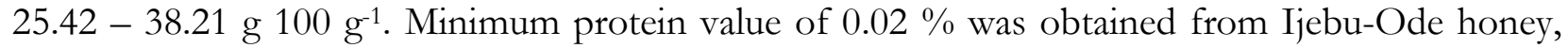
while the maximum of $0.51 \%$ was obtained from honey samples from Ilisan. Results of the elemental nutrient showed that potassium was the most abundant element in honey samples with the range value of $14.78-17.42 \mathrm{mg} 100 \mathrm{~g}^{-1}$ followed by calcium, which varied from $2.13-11.25$ mg $100 \mathrm{~g}^{-1}$. However, result of microbiological properties showed that the total plate count varied from $0.2-3.4 \mathrm{cfu} \mathrm{g}^{-1}$, whereas total coliforms were not detected in honey samples collected from Ago-Iwoye, Otta, Ibefun, Ife and Sagamu. Clostridium spp, Bacillus spp and yeast were also detected at low count in all honey samples investigated.

Moreover, honey samples obtained from different parts of Ogun State were found to be contaminated with Pseudomonas spp., Xanthomonas spp., Bacillus spp., E. coli and Clostridium spp, while fungi spores intercepted were Pennicillium oxalicum, Aspergilus niger, A. Flavus and Fusarium oxysporum at different levels and counts.
\end{abstract}

Key words: $\quad$ Hydroxymethylfurfural, Proline, Apis mellifera, Clostridium spp.

${ }^{1}$ Federal College of Agriculture, P. M. B. 5029, Ibadan. Oyo State. Nigeria.

2Department of Plant Science and Applied Zoology, Olabisi Onabanjo University,

Ago-Iwoye. Ogun State. Nigeria.

${ }^{3}$ Federal College of Animal Health and Production Technology, P. M. B. 5029, Ibadan. Oyo State. Nigeria.

Corresponding Author: Dr. Adenekan, M. O. Federal College of Agriculture, P. M. B. 5029, Ibadan. Oyo State. Nigeria

(mopadenekan@yahoo.com) 


\section{INTRODUCTION}

Honey is the sugary substance produced from the nectar of flowers by worker bees (Alfred, 2004). It is the most important primary product of beekeeping both from a quantitative and economic point of view. It was the first bee product used by mankind in ancient times (Crane, 1980).

China, Turkey and the United States of America are the top producers of natural honey (Krell, 1996). US honey production in 2007 was 148 million pounds, while Canada had an annual honey production of 62 million pound in 2008 (USDA, 2008). Honey contains mainly sugars (NHB, 2008). It contains more carbohydrates $(82.3 \%)$ than any other animal product (Lawal et al., 2009). According to McNulty (2002), the glucose and fructose component averages to about $76-80$ percent of the honey, while water accounts for about $17-20$ percent. The amount of amino acids and proteins in honey are relatively small ( 0.7 percent); thus having relatively small nutritive effects. However, these components can be important for judging honey quality (Cottee, 2004).

Several investigations have shown that the trace element contents of honey depend mainly on the botanical origin of the honey (Feller et al., 1989). Honey contains varying amount of mineral substances ranging from $0.02-$ $1.03 \mathrm{~g} 100 \mathrm{~g}^{-1}$. The main element found in honey is potassium with an average of about one-third of the total (Bogdanov et al., 2007). The acid content of honey is relatively low ranging from $\mathrm{pH}$ value of $3.3-4.6$, but it is important for honey taste (Echugo and Takenaka, 1974).

On account of the nutritional value and fast absorption of its carbohydrate, honey is a food suitable for humans of every age (Blasa et al., 2006). Honey is particularly recommended for children and sportsmen because it can help to improve the physiological activities immediately it is consumed and absorbed (Blasa et al., 2006).

The beneficial role of honey is attributed to its anti-bacterial and antiinflammatory properties with regard to its high osmolarity, acidity, and content of hydrogen peroxide $\left(\mathrm{H}_{2} \mathrm{O}_{2}\right)$ components (Weston, 2000). The anti-microbial agent in honey is predominantly hydrogen peroxide of which the concentration is determined by relative levels of inhibine and glucose oxidase (Weston, 2000).

Honey is farmed and used allover Nigeria. Initially, local farmers harvested honey from the wild, but today, apiculture is a growing industry in many 
parts of the country. Some studies on the healing effects and anti-microbial activity of Nigerian honey on burns and wounds have been reported (Adesunkanmi and Oyelami, 1994). However, there is no detailed study on the nutritional and microbiological characteristics of the honey produced in Ogun State. This study therefore investigated the nutritional and microbiological components of honey samples obtained from different parts of Ogun State, Southwestern Nigeria.

\section{MATERIALS AND METHODS}

\section{Sample Collection}

Honey samples used for this study were collected from different locations in Ogun State, Southwestern Nigeria. Ten (10) samples of honey were separately collected in sterilized glass bottles in 2008, 2009 and 2010 respectively. These samples were kept in dark cupboard and separately analyzed at the Biochemistry and Microbiology laboratories of the International Institute of Tropical Agriculture (IITA), Ibadan, Oyo State. Nigeria.

\section{Physicochemical Analyses}

The $\mathrm{pH}$ of honey samples obtained from different locations in Ogun State were measured with the $\mathrm{pH}$ meter (UNICAM 9450). $10 \mathrm{ml}$ of honey sample was taken and mixed in a beaker with $10 \mathrm{ml}$ of ultra-pure water and shaken for $20 \mathrm{~min}$ and allowed to stand for 15 - $20 \mathrm{~min}$ before the electrode was inserted. Readings were taken for all honey samples in triplicates to allow for statistical analysis (AOAC, 1990).

\section{Moisture Content Analysis}

One-hundred gramme of honey sample each was weighed accurately in a pre-weighed platinum dish and gently heated in a muffle furnace at 105 ${ }^{0} \mathrm{C}$ until the sample turned black and dried. This was allowed to cool in a dessicator and re-weighed again until a constant weight was obtained.

The weight loss in respect of $100 \mathrm{~g}$ represented the moisture contents of the honey sample. The percentage moisture content (MC) was calculated for all samples using the formula below: 


$$
\% \mathrm{MC}=\frac{\underline{\mathrm{M}}_{1}-\mathrm{M}_{2}}{\mathrm{M}_{1}-\mathrm{M}_{0}} \times 100
$$

Where $\mathrm{M}_{0}=$ wt $(\mathrm{g})$ of dish

$\mathrm{M}_{1}=\mathrm{wt}(\mathrm{g})$ of dish of honey sample before drying

$\mathrm{M}_{2}=\mathrm{wt}(\mathrm{g})$ of dish of honey sample after drying

\section{Determination of Ash content}

Honey sample $(2 \mathrm{~g})$ was ashed by calculation in a furnace at $600{ }^{\circ} \mathrm{C}$ to a constant weight. Ash percentage was calculated for all honey samples as: $\%$ Ash $=$ (Wt. of crucible + ash $)-$ Wt. of empty crucible $\mathrm{x}$ 100

Wt. of honey sample

\section{Measurement of Refractive Index (RI) and Acidity}

Refractive Index of honey samples was measured using the Refractometer at a constant temperature of $20{ }^{\circ} \mathrm{C}$ (AOAC, 1990). Honey acidity was determined by the trimetric method. $10 \mathrm{~g}$ of each honey sample was accurately dissolved in $75 \mathrm{ml} \mathrm{CO}_{2}$ free distilled and titrated with $0.1 \mathrm{~m}$ $\mathrm{NaOH}$ solution. Total acidity was obtained by adding free and lactonic acidities (Malika et al., 2005). Results were expressed as milli-equivalent of acid per kilogram (meq $\mathrm{kg}^{-1}$ ) of honey.

\section{Determination of Hydroxylmethylfurfural (HMF)}

Ten (10) grammes of each unheated sample was dissolved in $20 \mathrm{ml}$ ultra-pure water and thereafter transferred to $50 \mathrm{ml}$ volumetric flask and made up to $50 \mathrm{ml} .2 \mathrm{ml}$ of each sample was introduced into 2 test tubes and $5.0 \mathrm{ml}$ solution was added to each tube. The blank was prepared by adding $1 \mathrm{ml}$ barbituric acid to a tube with $1 \mathrm{ml}$ of ultra-pure water. The absorbance of the test sample was read against the blank at $550 \mathrm{~nm}$ wavelength using the spectrophotometer (Spectronic $20 \mathrm{D}$ model). The HMF was calculated using the equation proposed by Winker (1955).

$$
\mathrm{HMF}\left(\operatorname{mg} 100 \mathrm{~g}^{-1}\right)=\frac{\text { Absorbance }}{\text { Cell path length }} \times 100
$$

\section{Determination of sugar content}

The phenol-sulphuric acid method of Majnard (1970) was used. 10 $\mathrm{ml}$ of each honey sample ultra-pure water in a calibrated and centrifuged to 
obtain a supernatant solution for the analysis. $1 \mathrm{ml}$ of the diluted solution was pipette into test tube and $1 \mathrm{ml}$ of $52 \%$ phenol was added to each test tube. $5 \mathrm{ml}$ of $96 \% \mathrm{H}_{2} \mathrm{SO}_{4}$ was also added in drops. The test tube was then allowed to stand for 10 min before the content was transferred into clean grease-free cubettes. Stock glucose was prepared as standard. The values of the reducing sugar (fructose and glucose) present in each honey sample were read on a spectrophotometer at a wavelength of $490 \mathrm{~nm}$.

\section{Determination of crude protein (CP)}

Honey samples were analyzed for crude using the routine Kjeldahl nitrogen method (Joslyn, 1970). $10 \mathrm{~g}$ of the homogenous honey sample was weighed into digestion flask and dissolved with $10 \mathrm{ml}$ of ultra-pure water. The diluent was transferred into the volumetric flask, while Kjeldahl catalyst tablet (potassium sulphate) was added and thoroughly shaken. $20 \mathrm{ml}$ of concentrated $\mathrm{H}_{2} \mathrm{SO}_{4}$ was added and fixed into the digester. The flask was cooled and the digest transferred into $100 \mathrm{ml}$ volumetric flask. 5 drops of bromocresol (indicator) and $75 \mathrm{ml}$ of ultra-pure water were added. $10 \mathrm{ml}$ of the digest was pipette into the Kjeldahl distillation flask and titrated with $0.05 \mathrm{~N}$ of $\mathrm{HCl}$, while the percentage total nitrogen was calculated using the Joslyn (1970) equation.

$\%$ Total nitrogen $\quad=\quad \underline{14.0 \text { (sample titre }- \text { blank titre) }}$

X N

Where $\mathrm{N}=$ normality of acid

$10 \mathrm{x}$ wt of sample

$\%$ CP was obtained for all the honey samples by:

$\% \mathrm{CP}=\%$ total nitrogen $\times 6.25$

\section{Mineral Element Analysis}

The honey samples were analyzed for mineral elemental determination using Atomic Absorption Spectrophotometer (AAS) and Flame Photometer according to AOAC (2005). $10 \mathrm{~g}$ of honey sample was weighed and dissolved in ultra-pure water after thorough mixing; the solution was stirred for $15 \mathrm{~min}$ on a mechanical stirrer at $1550 \mathrm{rpm}$. A solution of Parkloric acid and nitric acid were added and mixed thoroughly. This homogenous solution was dispensed into the AAS in order to determine the concentration of $\mathrm{K}, \mathrm{Ca}, \mathrm{Mg}, \mathrm{Cu}$ and $\mathrm{P}$ at different wavelengths. A standard was prepared for each of these elements. 


\section{Microbiological analysis}

The total plate count method was used for culturing and isolating the different microbes intercepted in the honey samples. MacConkey agar was used as the medium for microflora culture, while Potato dextrose agar was used for growing fungi (Marshall, 1987). Bacteria colonies resulting from the first culture after incubation at $35^{\circ} \mathrm{C}$ for $48 \mathrm{hrs}$ were transferred to fresh media, streaked and incubated again. This sequential streaking, based on the principle of dilution of culture helped to produce discrete bacterial colonies after incubation. After successive transfer, the resulting pure isolates were gram-stained and identified based on colour, size and shape with reference to the manual of Determinative Biology (Beckatt and Stelanke, 1986).

For fungi, incubation was at room temperature $\left(25-27^{\circ} \mathrm{C}\right)$ for 4 days. The resulting mycelia were extracted and grown respectively on malt extract and potato dextrose agar until pure cultures were obtained. In addition to structural morphology of fungi, other identification characteristics such as cultural, surface appearances of colonies and the colour of the colonies were also used. Other parameters considered were the nature of mycelia: septate or non-septate, conidia heads, nature and arrangement of spores (Bradshaw, 1979).

\section{Statistical analysis}

Data generated from the laboratory analyses were subjected to statistical analyses using Analysis of Variance (ANOVA), while the sample means were separated with the aid of Duncan Multiple Range Test at $\mathrm{P} \leq$ 0.05 (SAS, 1999). All values were expressed as the mean standard deviation.

\section{RESULTS AND DISCUSSION}

\section{Physicochemical Characteristics}

The mean physicochemical components of the samples of honey obtained from different parts of Ogun State in 2008, 2009 and 2010 are presented in Tables 1 and 2. The mean $\mathrm{pH}$ values of the honey samples ranged from $3.48-5.21$. There was a significant difference in the mean $\mathrm{pH}$ value of $5.06 \pm 1.11$ obtained from Abeokuta and the mean value of $3.77 \pm$ 0.61 obtained from Sagamu, but was not different significantly from the $\mathrm{pH}$ mean values of 5.21 and 5.16 obtained from Ibefun and Ayetoro honey 
samples respectively. The mean $\mathrm{pH}$ range obtained in this study was however closer to the range of $4.31-6.0$ reported for Nigerian honey from other locations (Adebuyi et al., 2004). The acidic pH of honey has been shown to promote

Table 1:Mean physical characteristics of honey samples obtained from some locations in Ogun State Western Nigeria for 2008, 2009 and 2010

\begin{tabular}{lllll}
\hline Source & $\mathrm{pH}$ value & $\mathrm{MC}(\%)$ & Ash $(\%)$ & RI \\
\hline Abeokuta & $5.06 \pm 1.11^{\mathrm{a}}$ & $21.41 \pm 1.31^{\mathrm{a}}$ & $0.78 \pm 0.21^{\mathrm{b}}$ & $1.02 \pm 0.01^{\mathrm{c}}$ \\
Ijebu-Ode & $4.62 \pm 0.31^{\mathrm{b}}$ & $18.21 \pm 2.11^{\mathrm{b}}$ & $0.54 \pm 0.11^{\mathrm{c}}$ & $1.31 \pm 0.01^{\mathrm{b}}$ \\
Ago-Iwoye & $3.48 \pm 0.35^{\mathrm{d}}$ & $19.17 \pm 2.16^{\mathrm{a}}$ & $0.75 \pm 0.12^{\mathrm{b}}$ & $1.18 \pm 0.01^{\mathrm{b}}$ \\
Ayetoro & $5.16 \pm 0.71^{\mathrm{a}}$ & $20.13 \pm 1.47^{\mathrm{a}}$ & $0.84 \pm 0.22^{\mathrm{a}}$ & $1.86 \pm 0.13^{\mathrm{a}}$ \\
Ogere & $4.31 \pm 0.43^{\mathrm{b}}$ & $16.19 \pm 1.32^{\mathrm{c}}$ & $0.36 \pm 0.06^{\mathrm{d}}$ & $1.77 \pm 0.11^{\mathrm{a}}$ \\
Otta & $3.97 \pm 0.14^{\mathrm{c}}$ & $19.14 \pm 1.31^{\mathrm{a}}$ & $0.41 \pm 0.11^{\mathrm{c}}$ & $1.10 \pm 0.02^{\mathrm{b}}$ \\
Ibefun & $5.21 \pm 0.23^{\mathrm{a}}$ & $21.27 \pm 3.16^{\mathrm{a}}$ & $0.34 \pm 0.14^{\mathrm{d}}$ & $1.13 \pm 0.11^{\mathrm{b}}$ \\
Ilisan & $4.06 \pm 1.34^{\mathrm{c}}$ & $16.15 \pm 1.27^{\mathrm{c}}$ & $0.32 \pm 0.01^{\mathrm{d}}$ & $1.21 \pm 0.01^{\mathrm{b}}$ \\
Ifo & $3.74 \pm 0.21^{\mathrm{c}}$ & $20.16 \pm 2.16^{\mathrm{a}}$ & $0.77 \pm 0.03^{\mathrm{b}}$ & $1.24 \pm 0.01^{\mathrm{b}}$ \\
Sagamu & $3.77 \pm 0.61^{\mathrm{c}}$ & $16.28 \pm 1.71^{\mathrm{c}}$ & $0.96 \pm 0.21^{\mathrm{a}}$ & $1.07 \pm 0.03^{\mathrm{c}}$ \\
Range & $3.48-5.21$ & $16.15-21.41$ & $0.32-0.96$ & $1.02-1.86$ \\
\hline
\end{tabular}

MC - Moisture content

$\mathrm{RI}$ - Refractive index

Table 2: Mean HMF, free lactone and free total acidity of honey samples obtained from some locations in Ogun State for 2008, 2009 and 2010

\begin{tabular}{lcccc}
\hline Source & $\begin{array}{c}\text { HMF } \\
\left(\mathrm{mg} 100 \mathrm{~g}^{-1}\right)\end{array}$ & $\begin{array}{c}\text { Free acidity } \\
\left(\mathrm{meq} \mathrm{kg}^{-1}\right)\end{array}$ & $\begin{array}{c}\text { Lactonic acid } \\
\left(\mathrm{meq} \mathrm{kg}^{-1}\right)\end{array}$ & $\begin{array}{c}\text { Total acidity } \\
\left(\mathrm{meq} \mathrm{kg}^{-1}\right)\end{array}$ \\
\hline Abeokuta & $1.27 \pm 0.31^{\mathrm{b}}$ & $20.1 \pm 2.11^{\mathrm{c}}$ & $11.4 \pm 1.14^{\mathrm{b}}$ & $31.5^{\mathrm{c}}$ \\
Ijebu-Ode & $0.39 \pm 0.04^{\mathrm{c}}$ & $18.6 \pm 1.67^{\mathrm{c}}$ & $5.7 \pm 0.21^{\mathrm{c}}$ & $24.3^{\mathrm{f}}$ \\
Ago-Iwoye & $1.11 \pm 0.06^{\mathrm{b}}$ & $25.7 \pm 3.14^{\mathrm{b}}$ & $9.1 \pm 1.15^{\mathrm{b}}$ & $34.8^{\mathrm{c}}$ \\
Ayetoro & $0.48 \pm 0.11^{\mathrm{c}}$ & $20.8 \pm 1.21^{\mathrm{c}}$ & $9.7 \pm 1.10^{\mathrm{b}}$ & $30.5^{\mathrm{c}}$ \\
Ogere & $1.37 \pm 0.14^{\mathrm{b}}$ & $29.4 \pm 1.75^{\mathrm{a}}$ & $10.2 \pm 0.94^{\mathrm{b}}$ & $39.6^{\mathrm{b}}$ \\
Otta & $0.34 \pm 0.06^{\mathrm{c}}$ & $14.3 \pm 3.11^{\mathrm{d}}$ & $6.4 \pm 1.23^{\mathrm{b}}$ & $20.7^{\mathrm{e}}$ \\
Ibefun & $1.17 \pm 0.15^{\mathrm{b}}$ & $19.7 \pm 1.32^{\mathrm{c}}$ & $8.9 \pm 0.41^{\mathrm{c}}$ & $28.6^{\mathrm{d}}$ \\
Ilisan & $1.63 \pm 0.16^{\mathrm{a}}$ & $27.5 \pm 2.17^{\mathrm{a}}$ & $12.1 \pm 2.11^{\mathrm{b}}$ & $39.6^{\mathrm{b}}$ \\
Ifo & $1.25 \pm 0.03^{\mathrm{b}}$ & $27.8 \pm 1.42^{\mathrm{a}}$ & $11.7 \pm 1.44^{\mathrm{b}}$ & $39.5^{\mathrm{b}}$ \\
Sagamu & $0.32 \pm 0.12^{\mathrm{c}}$ & $30.4 \pm 2.97^{\mathrm{a}}$ & $14.3 \pm 1.30^{\mathrm{a}}$ & $44.7^{\mathrm{a}}$ \\
Range & $0.32-1.63$ & $14.3-30.4$ & $5.7-14.3$ & $20.7-44.7$ \\
\hline
\end{tabular}

healing by causing oxygen release from haemoglobin (Leveen et al., 1973). The $\mathrm{pH}$ of honey is low enough to prevent the growth of many species of pathogenic organisms. 
The moisture content (MC) of honey samples varied from $16.15-21.41 \%$ (Table 1). The highest MC of $21.41 \%$ was obtained from the honey sample collected from Abeokuta, which was significantly different from the lowest value of $16.15 \%$ obtained from Ilisan, but not significantly different from 19.17, 20.13, 21.27 and 20.16\% obtained from honey samples collected from Ago-Iwoye, Ayetoro, Ibefun and Ifo respectively. The MC in honey samples collected from Ogun State for the years under study was comparable to the values obtained by Omafuvbe and Akanbi (2009) for Nigerian honey and differs slightly from US honey as reported by White (1975b). The variation observed from the mean MC can be explained by the composition and floral origin in honey samples collected from different locations in Ogun State. An increase in MC is indicative of adulteration. Low MC in honey also forms an important part of the system which protects honey from the attack by microorganisms.

There were significant differences in the mean ash content in honey samples collected from various locations of Ogun State, Nigeria. The ash content ranged between $0.32-0.96 \%$ (Table 1 ). The mean ash content of $0.84 \%$ obtained from Ayetoro was significantly different from 0.36 and $0.34 \%$ obtained from Ogere and Ibefun honey samples respectively. Ash represents a direct measure of inorganic residue after honey carbonation. The variability in the ash content observed could be explained by the floral origin, geographical location and level of maturity of the honey. However, the mean ash content obtained value of $0.61 \%$ is closer to $0.66 \%$ obtained for honey in the Sudano-Guinea zone of western Cameroun (Tchoumborne et al., 2007).

The highest mean refractive index (RI) of 1.86 was obtained from the honey samples collected from Ayetoro, which was significantly different from the lowest mean value of 1.02 obtained from Abeokuta honey sample, but not significantly different from the mean value of 1.77 obtained from the honey samples collected from Ogere. These values are similar to $1.46-$ 1.48 reported by Adebiyi et al. (2005).

The results showed that honey samples from Abeokuta, Ijebu-Ode, AgoIwoye and Ayetoro had mean hydroxymethylfurfural (HMF) content of 1.27, 0.39, 1.11 and $0.48 \mathrm{mg} 100 \mathrm{~g}^{-1}$, while samples from Ogere, Otta, Ibefun, Ilisan, Ifo and Sagamu had mean HMF constituents of 1.37, 0.34, $1.17,1.63,1.25$ and $0,32 \mathrm{mg} 100 \mathrm{~g}^{-1}$ respectively (Table 2 ). The mean value of HMF obtained showed that it occurred only in trace amounts as 
reported by Thrasyvoulou (1997). The HMF measures the quality of honey formation of 5-hydroxymethyl-furfuraldehyde by acid hydrolysis of its sucrose with the formation of red colour.

The values for free lactone and total acidities are summarized in Table 2. Mean free acidity ranged between 14.3 - 30.4 meq $\mathrm{kg}^{-1}$, lactone acidity values were between $5.7-14.3$ meq $\mathrm{kg}^{-1}$, while total acidity values varied from 20.7 - 44.7 meq kg-1. The total acidity of 39.6 meq $\mathrm{kg}^{-1}$ obtained from Ilisan honey, which was not significantly different from the mean values of 39.5 and $44.7 \mathrm{meq} \mathrm{kg}^{-1}$ obtained from the honey samples collected from Ifo and Sagamu respectively, but was different significantly from the mean values of 31.5, 20.7 and 28.6 meq kg-1 obtained from the honey samples collected from Abeokuta, Otta and Ibefun respectively (Table 2).

The mean values obtained for total acidity of honey samples obtained from the honey samples collected from different locations in Ogun State falls within the range reported for Moroccan honey (Malika et al., 2005). The acidity of honey contributes to its stability against microorganisms and flavor (Omafuvbe and Akanbi, 2009).

\section{Nutritional Constituents}

The mean nutrient contents of honey samples obtained from different locations in Ogun State for 2008, 2009 and 2010 are presented in

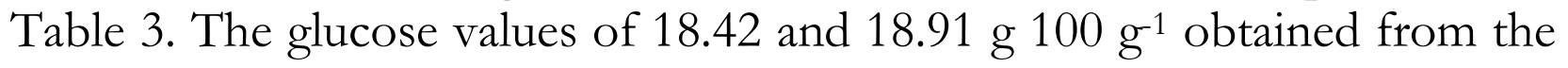
honey samples collected from Abeokuta and Ijebu-Ode respectively are significantly different from the mean value of 25.32 and $30.1 \mathrm{~g} 100 \mathrm{~g}^{-1}$ obtained from Ogere and Ilisan honey samples respectively. The fructose values obtained in honey samples collected ranged from $25.42-38.21 \mathrm{~g} 100$ $\mathrm{g}^{-1}$. This showed that fructose and glucose sugars are the major sugars found in honey. This result is in conformity with the research reported by Krell (1996) that the majority of sugars in honey are the simple sugars, fructose and glucose, which represents about 85 - $95 \%$ of total sugars found in honey. Generally, fructose sugar is greater than glucose sugar for honeys collected from different parts of Ogun State. This is in agreement with the report of Crane (1990) who reported that fructose is more abundant than glucose in US honey. 
Table 3:Mean nutritional components of honey samples obtained from some locations in Ogun State for 2008, 2009 and 2010

\begin{tabular}{|c|c|c|c|c|c|c|c|c|}
\hline \multirow[t]{2}{*}{ Source } & Glucose & Fructose & $\mathrm{CP}$ & $\mathrm{K}$ & $\mathrm{Ca}$ & $\mathrm{Mg}$ & $\mathrm{Cu}$ & $\mathrm{P}$ \\
\hline & \multicolumn{2}{|c|}{$\left(\mathrm{g} 100 \mathrm{~g}^{-1}\right)$} & \multicolumn{2}{|l|}{ ns } & & \multicolumn{3}{|c|}{$\left(\right.$ meq $\left.100 \mathrm{~g}^{-1}\right)$} \\
\hline Abeokuta & $18.42 \pm$ & $25.42 \pm$ & $0.12 \pm$ & $14.78 \pm$ & $6.31 \pm$ & $0.19 \pm$ & $0.03 \pm$ & $1.06 \pm$ \\
\hline \multirow{2}{*}{ Ijebu-Ode } & $\begin{array}{l}2.14 \mathrm{c} \\
18.91+\end{array}$ & $\begin{array}{l}1.23 \mathrm{c} \\
30.46+\end{array}$ & $\begin{array}{l}0.01 \\
0.02+\end{array}$ & $\begin{array}{l}1.010 \\
16.51+\end{array}$ & $\begin{array}{l}1.11^{\mathrm{D}} \\
4.50+\end{array}$ & $\begin{array}{l}0.20^{\mathrm{a}} \\
0.15+\end{array}$ & $0.01^{\mathrm{a}}+$ & $\begin{array}{l}0.02^{a} \\
1.18+\end{array}$ \\
\hline & $1.67 \mathrm{c}$ & $2.14^{\mathrm{b}}$ & 0.01 & $1.02^{a}$ & $0.16^{\mathrm{c}}$ & $0.04^{c}$ & $0.01^{\mathrm{c}}$ & $0.04^{a}$ \\
\hline \multirow[t]{2}{*}{ Ago-Iwoye } & $28.64 \pm$ & $30.82 \pm$ & $0.36 \pm$ & $17.42 \pm$ & $4.10 \pm$ & $0.23 \pm$ & $0.03 \pm$ & $0.96 \pm$ \\
\hline & $3.21^{\mathrm{a}}$ & $1.77 \mathrm{~b}$ & 0.03 & $1.62^{\mathrm{a}}$ & $0.31^{\mathrm{c}}$ & $0.01^{b}$ & $0.00^{\mathrm{d}}$ & $0.04^{c}$ \\
\hline \multirow[t]{2}{*}{ Ayetoro } & $28.71 \pm$ & $37.11 \pm$ & $0.07 \pm$ & $16.76 \pm$ & $4.23 \pm$ & $0.24 \pm$ & $0.07 \pm$ & $1.67 \pm$ \\
\hline & $1.76^{\mathrm{ba}}$ & $3.60^{\mathrm{a}}$ & 0.02 & $2.10^{a}$ & $0.14^{c}$ & $0.01^{b}$ & $0.02^{c}$ & $0.03^{a}$ \\
\hline \multirow[t]{2}{*}{ Ogere } & $25.32 \pm$ & $30.06 \pm$ & $0.38 \pm$ & $16.20 \pm$ & $3.32 \pm$ & $0.17 \pm$ & $0.12 \pm$ & $1.32 \pm$ \\
\hline & $3.11^{\mathrm{b}}$ & $3.60^{\mathrm{b}}$ & 0.01 & $1.67^{\mathrm{a}}$ & $0.12^{c}$ & $0.01^{c}$ & $0.01^{\mathrm{b}}$ & $0.04^{a}$ \\
\hline Otta & $\begin{array}{l}25.41 \pm \\
2.46^{\mathrm{b}}\end{array}$ & $\begin{array}{l}27.15 \pm \\
1.24 c\end{array}$ & $\begin{array}{l}0.17 \pm \\
0.02\end{array}$ & $\begin{array}{l}16.32 \pm \\
1.20^{a}\end{array}$ & $\begin{array}{l}3.35 \pm \\
0.11^{c}\end{array}$ & $\begin{array}{l}0.29 \pm \\
0.03 \mathrm{~b}\end{array}$ & $\begin{array}{l}0.05 \pm \\
0.01^{c}\end{array}$ & $\begin{array}{l}0.52 \pm \\
0.02^{b}\end{array}$ \\
\hline \multirow[t]{2}{*}{ Ibefun } & $26.11 \pm$ & $37.67 \pm$ & $0.24 \pm$ & $16.15 \pm$ & $2.13 \pm$ & $0.15 \pm$ & $0.13 \pm$ & $0.46 \pm$ \\
\hline & $1.21^{\mathrm{b}}$ & $1.36^{\mathrm{b}}$ & 0.01 & $1.31 \mathrm{a}$ & $0.17 \mathrm{~d}$ & $0.02^{c}$ & $0.01 \mathrm{~b}$ & $0.03 \mathrm{~b}$ \\
\hline \multirow[t]{2}{*}{ Ilisan } & $30.16 \pm$ & $31.52 \pm$ & $0.51 \pm$ & $16.24 \pm$ & $7.74 \pm$ & $0.20 \pm$ & $0.21 \pm$ & $1.32 \pm$ \\
\hline & $1.31^{\mathrm{a}}$ & $1.74 \mathrm{~b}$ & 0.03 & $1.21 \mathrm{a}$ & $1.19 \mathrm{~b}$ & $0.02^{\mathrm{d}}$ & $0.02^{\mathrm{a}}$ & $0.01 \mathrm{a}$ \\
\hline \multirow[t]{2}{*}{ Ifo } & $28.08 \pm$ & $38.21 \pm$ & $0.21 \pm$ & $15.11 \pm$ & $11.25 \pm$ & $0.74 \pm$ & $0.14 \pm$ & $1.37 \pm$ \\
\hline & $2.17^{a}$ & $2.30^{a}$ & 0.02 & $1.23^{b}$ & $1.34^{\mathrm{a}}$ & $0.11^{\mathrm{a}}$ & $0.01^{\mathrm{b}}$ & $0.03^{a}$ \\
\hline \multirow[t]{2}{*}{ Sagamu } & $29.16 \pm$ & $36.31 \pm$ & $0.09 \pm$ & $15.34 \pm$ & $6.31 \pm$ & $0.92 \pm$ & $0.09 \pm$ & $1.24 \pm$ \\
\hline & $1.95^{\mathrm{a}}$ & $1.37^{\mathrm{a}}$ & 0.01 & $1.31 \mathrm{~b}$ & $0.78^{\mathrm{b}}$ & $0.12^{a}$ & $0.02^{\mathrm{b}}$ & $0.02^{a}$ \\
\hline \multirow[t]{2}{*}{ Range } & $18.42-$ & $25.42-$ & $0.02-$ & $14.78-$ & $2.13-$ & $0.15-$ & $0.03-$ & $0.46-$ \\
\hline & 30.16 & 38.21 & 0.51 & 17.42 & 11.25 & 0.92 & 0.21 & 1.67 \\
\hline
\end{tabular}

The protein content detected in honey samples collected from Ogun State is in small quantities with the highest value of $0.51 \%$ obtained from Ilisan honey sample, while the lowest value of $0.02 \%$ was obtained from IjebuOde honey sample. The mean value of $0.38 \%$ obtained from Ogere honey was significantly different from the mean values of $0.09,0.07$ and $0.12 \%$ obtained from the honey samples collected from Sagamu, Ayetoro and Abeokuta respectively (Table 3). This result is in agreement with the report of Terrab et al. (2003) who stated that honey is not intended as a protenacous food as the amount of protein are relatively small and at most $0.7 \%$.

The results of the atomic absorption spectrophotometric (AAS) analysis of the honey samples are presented in Table 3. Five elements were detected: $\mathrm{K}, \mathrm{Ca}, \mathrm{Mg}, \mathrm{Cu}$ and $\mathrm{P}$ at different concentrations in honey samples collected from different locations in Ogun State. $\mathrm{K}$ was the most abundant element

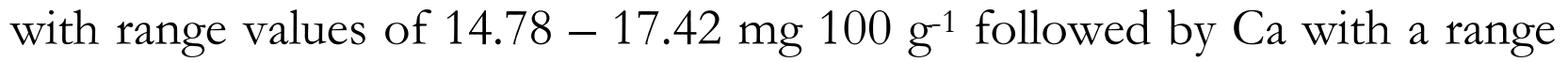
of $2.13-11.25 \mathrm{mg} 100 \mathrm{~g}^{-1}$, while $\mathrm{P}$ had value range of $0.46-1.67 \mathrm{mg} 100 \mathrm{~g}$ 1. The values of $\mathrm{Mg}$ and $\mathrm{Cu}$ were in trace amount, but varied from $0.15-$ 
0.92 and $0.03-0.21 \mathrm{mg} 100 \mathrm{~g}^{-1}$ respectively. However, there were significant differences in the elemental contents of honey samples collected from different locations in Ogun State (Table 3). These results are in agreement with the research carried out by Adebiyi et al. (2004) who reported that $\mathrm{K}$ was the most abundant element in Nigerian honey followed by $\mathrm{Ca}$. it then confirms that Ogun State honeys are quite rich in elemental nutrients, which are necessary for major physiological activities in human being.

\section{Microbiological Characteristics}

Microbial counts in samples of honey collected from different locations in Ogun State are reported in Table 4. The total bacterial count (TBC) showed that honey samples collected from Ogere had a count of $3.4 \times 10^{3} \mathrm{cfu} \mathrm{g}^{-1}$,

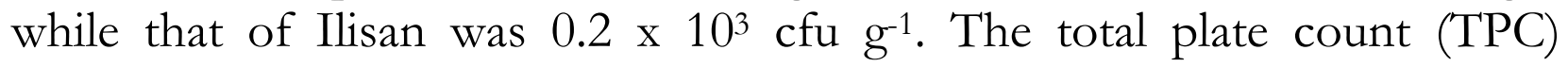
showed low level for all the honey samples obtained from different locations in Ogun State. The total coliform count (TCC) was also very low with a minimum of $0.3 \times 10^{3} \mathrm{cfu} \mathrm{g}^{-1}$ obtained from the honey samples collected from Abeokuta, while the maximum value of $2.0 \times 10^{3} \mathrm{cfu} \mathrm{g}^{-1}$ was obtained from the honey samples collected from Ogere. There were no coliform count in honey samples collected from Ayetoro, Otta, Ibefun, Ifo and Sagamu areas of Ogun State. This may be explained by the evidence that honey is well preserved against bacteria so that these organisms would not survive unfavourable conditions. This result is in agreement with the report that Moroccan honeys are very low in bacterial and coliform counts.

Table 4: Mean microbial count (x $10 \mathrm{Cfu} \mathrm{g}^{-1}$ ) of honey samples obtained from some locations in Ogun State for 2008, 2009 and 2010

\begin{tabular}{lcccccc}
\hline Source & TBC & TCC & TF & Clostridium spp. & Bacillus spp. & TYC \\
\hline Abeokuta & 1.8 & 0.3 & 0.6 & ++ & 1.4 & 3.0 \\
Ijebu-Ode & 2.3 & 1.5 & 0.1 & ++ & 0.1 & 1.0 \\
Ago-Iwoye & 1.4 & 1.2 & 0.6 & 1.4 & 1.7 & 1.4 \\
Ayetoro & 2.6 & ++ & 0.3 & ++ & ++ & 2.0 \\
Ogere & 3.4 & 2.0 & 0.8 & 0.6 & 2.0 & 6.4 \\
Otta & 2.4 & ++ & 1.4 & 0.2 & 1.4 & 2.8 \\
Ibefun & 1.7 & ++ & 0.3 & 0.1 & ++ & 2.1 \\
Ilisan & 0.2 & 1.4 & 0.4 & ++ & 0.3 & 2.7 \\
Ifo & 1.6 & ++ & 0.3 & 0.3 & 1.0 & 2.7 \\
Sagamu & 2.6 & ++ & 0.6 & ++ & 2.4 & 2.9 \\
\hline
\end{tabular}


Results are mean of 3 determinations

TCC - total coliform count

TF- the total fungi

$\mathrm{cfu}^{-1}$ - colony forming unit per gram
TBC - total bacterial count

TYC - total yeast count

$++=$ Absence of microbe

Clostridial and bacillus counts were also very low. In fact, there were clostridium count in most of the honey samples collected from Ogun State except those from Ago-Iwoye, Ogere, Otta, Ibefun and Ifo, which had clostridial counts of $1.4,0.6,0.2,0.1$ and $0.3 \times 10^{3} \mathrm{cfu} \mathrm{g}^{-1}$ respectively. No bacillus count was also recorded for honey samples collected from Ayetoro and Ibefun (Table 4). Our results are in agreement with the research carried out by Omafuvbe and Akanbi (2009) and Malika et al. (2005).

The results in this study clearly showed that honey samples collected from different locations in Ogun State have total fungal count between $0.1-1.4$ x $10^{3} \mathrm{cfu} \mathrm{g}^{-1}$. The total yeast count (TYC) obtained were also very low with a range of $1.0-6.4 \times 10^{3} \mathrm{cfu}^{-1}$ in honey samples collected from Ijebu-Ode and Ogere respectively (Table 4). This variation in TYC may be due to the type of harvesting, processing and freshness of the honey. The low count of fungal and yeast cells are in accord with the report of Tysett et al. (1970) who reported that French honey had zero count of yeast and moulds. The absence of fungal spores and yeast cells in some of the honey samples confirms that honey has inherent antimicrobial properties that can delay the growth of many microorganisms. Generally, honey may contain organisms from bees, soil, air and dust that may be introduced during post-harvest handling (Jay, 1992).

The occurrence of bacteria detected in honey samples collected from different locations in Ogun State is presented in Table 5. The bacteria found in the honey samples were identified as Pseudomonas spp., Xanthomonas spp., Bacillus spp., Escherichia coli, and Clostridium spp. These are plant pathogens, except Bacillus spp., E. coli, and Clostridium spp.; hence, originated from the plant host containing the nectars where the bees visited. The Clostridium and E. coli bacteria were detected in very small count in the honey samples investigated. This is an indication that the sanitary conditions during extraction and handling in the apiaries were quite efficient. This result is in agreement with the research of Omafuvbe and Akanbi (2009) and Adenekan et al. (2010) who reported that commercial honey in Nigeria does not harbour spores of E. coli and Clostridium spp. 
Table 5: Occurrence of bacteria detected in honey samples obtained from some locations in Ogun State for 2008, 2009 and 2010

\begin{tabular}{lccccc}
\hline Source & Pseudomona spp. & $\begin{array}{c}\text { Xanthomonas } \\
\text { spp. }\end{array}$ & Bacillus spp. & E. coli & Clostridium spp. \\
\hline Abeokuta & ++ & ++ & ++ & ++ & -- \\
Ijebu-Ode & ++ & -- & -- & ++ & -- \\
Ago-Iwoye & ++ & -- & ++ & ++ & ++ \\
Ayetoro & ++ & ++ & -- & -- & - \\
Ogere & ++ & ++ & ++ & ++ & ++ \\
Otta & ++ & ++ & ++ & -- & ++ \\
Ibefun & ++ & -+ & -- & ++ & ++ \\
Ilisan & ++ & -- & -- & - \\
Ifo & ++ & ++ & ++ & -- & -+ \\
Sagamu & ++ & ++ & ++ & & -- \\
\hline
\end{tabular}

Results are mean of 3 determinations

$++=$ presence of bacterial spore

-- $=$ absence of bacterial spore

The results in this study showed that honeys collected from different locations in Ogun State harbor arrays of fungal contamination. The fungal spores found in the honey samples were identified as Pennicillium oxalicum, Aspergillus niger, A. flavus and Fusarium oxysporum and their occurrence pattern is presented in Table 6 . The fungal arrays detected are not known to be pathogenic to human beings and this confirms the report of Tchoumboue et al. (2007) that eight fungal species were identified from the western Cameroun honey. It is also in conformity with the report of other researchers that fungi and spore-forming bacteria may be present in honey for a limited period of time (Anon, 2001). The occurrence of these fungi in honey could be an indication of contamination from secondary sources during handling, processing and storage or adulteration (Adenekan et al., 2010). 
Table 6: Occurrence of fungal and yeast organisms detected in honey samples obtained from some locations in Ogun State for 2008, 2009 and 2010

\begin{tabular}{lccccc}
\hline Source & $\begin{array}{c}\text { Penicillum } \\
\text { oxalicum }\end{array}$ & Aspergillus niger & $\begin{array}{c}\text { Aspergillus } \\
\text { flavus }\end{array}$ & Fusarium oxysporum & Yeast cell \\
\hline Abeokuta & ++ & ++ & ++ & ++ & ++ \\
Ijebu-Ode & -- & ++ & ++ & -- & ++ \\
Ago-Iwoye & ++ & ++ & -- & -- & ++ \\
Ayetoro & ++ & -- & -- & -- & ++ \\
Ogere & ++ & ++ & ++ & ++ & ++ \\
Otta & ++ & -- & ++ & ++ & ++ \\
Ibefun & -- & -- & -+ & -- & ++ \\
Ilisan & -- & -+ & -- & ++ \\
Ifo & ++ & - & -+ & ++ \\
Sagamu & ++ & ++ & -- & ++ \\
\hline
\end{tabular}

Results are mean of 3 determinations

$++=$ presence of fungal organism

$--=$ absence of fungal cells

\section{REFERENCES}

Adebiyi, F. M., I. Akpan, E. T. Obiajunwa and H. B. Olaniyi (2004). Chemical / physical characterization of Nigerian honey. Pakistan Journal Nutrition 3 (5): $278-291$.

Adenekan, M. O., N. A. Amusa, A. O. Lawal and V. E. Okpeze (2010). Physicochemical and microbial properties of honey samples obtained from Ibadan. Journal of Microbiological and Antimicrobia 2 (8): 100 - 104.

Adesunkanmi, K. and O. A. Oyelami (1994). The pattern and outcome of burn injuries at Wesley Guild Hospital, Ilesa. Nigeria. A review of 156 cases. Journal of Tropical Medical Hygiene 97: 108 - 112.

Alfred, W. C. (2004). Ecological imperialism: The Biological Expansion 2. Education Cambridge University Press, Cambridge. pp. ISBN-10-0521546184.

Anon (2001). Bee, honey: Natural products Almalelka: http://naturalproduct.almaleka.com/bproducts/honey/hl.ttm. Retrieved March 10, 2009.

AOAC (1990). Food composition, additives, natural contaminants. Aldrich Rqs. (ed.) vol $215^{\text {th }}$ edition. Official methods of analysis. Association of Official Analytical Chemists Inc. USA.

Beckatt, H. H. and J. D. Stelanke (1986). Microbial contamination. In: Practical pharmaceutical chemistry $3^{\text {rd }}$ ed. London: Wilhan Heinemann Medical Book Ltd. pp. 4 - 7 ISBN 42-0501391-7.

Blassa, M. M. Cabdracci, A. Accorti, M. P. Placentini, M. C. Albertini and E. Patti (2006). Raw milleformi honey is packed full of antioxidants. Food Chemistry 97: $217-222$.

Bogdanov, S., M. Haldimann, W. Luginbuhl and P. Gallman (2007). Minerals in honey: Environmental, geographical and botanical aspects. Journal of Agricultural Research and Bee World 46 (4): 269 - 275. 
Bradshaw, L. J. (1979). Laboratory microbiology 3 ${ }^{\text {rd }}$ ed. W. B. Sounder Co, New York. pp. 107 - 115. ISBN 43-0210319-4.

Cotte, J. F., H. Cassabianca, B. Giroud, M. Albert, J. Lheritier and M. F. Gremuloustalot (2004). Characterization of honey amino acid profiles using high-pressure liquid chromatography to control authenticity. Analytical and Bio-analytical Chemistry 378 (5): $1342-1350$.

Crane, E. (1980). A book of honey. Oxford University Press, Oxford. UK. pp. 288 - 290. ISBN 29-0315019-0

Crane, E. (1990). Bees and beekeeping science, practice and world resources. Cornstock Publ. Ithaca, New York, USA. 593pp.

Echigo, T. and T. Takenaka (1974): Production of organic acids in honey by honeybees. Journal of Chemists Society Japan 48 (4): 225 - 230.

Feller-Demalsy, M. J., B. Vincent and F. Beulieu (1989). Mineral content and geographical origin of Canadian honeys. Apidoligie 20 (1): 77 - 91.

Jay, J. M. (1992). Modern food microbiology. Chapman and Hall, New York. 642p.

Joslyn, A. M. (1970). Methods in food analysis $2^{\text {nd }}$ ed. A series of monographs. Academic Press New York. pp. $542-559$.

Krell, R. (1996). Value added products from beekeeping. FAO Agric. Serv. Bulletin No. 124, Rome. Italy. ISBN 62-5030119-6.

Lawal, R. A., A. K. Lawal and J. B. Adekalu (2009). Physicochemical studies on adulteration of honey in nigeria. Pak Journal of Biological Sciences 12 (15): 1080 - 1084.

Leveen, H. H., G. Falk and K. B. Bore (1973). Chemical acidification of wounds: An adjuvant to healing and the unfavourable action of alkalinity and ammonia. American Surgical 187: 745 - 753 .

Lurlina, M. O. and R. Fritz (2005). Characteristion of microorganisms in Argentinean honeys from different sources. International Journal Food Microbiology 105: 297 - 304.

Malika, N., F. Mohammed and E. Chakib (2005). Microbiological and physicochemical properties of Moroccan honey. International Journal of Agricultural Biology 7 (5): 773 776.

Maynard, A. J. (1970). Methods in food analysis $2^{\text {nd }}$ ed. A series of monographs. Academic Press New York. pp. $112-136$.

McNulty, M. (2006). How products are made: In (ed.) Blenchfield, D. an illustration guide to products manufacturing. Detroit: Gale Group 87 - 91pp. ISBN 78-119503-4.

NHB (2008): Why do bees make honeys? National Honey Board www.honeyboard.org.com. Retrieved Nov. 4, 2008.

Omafuvbe, B. O. and O. O. Akanbi (2009). Microbiological and physicochemical properties of some commercial Nigerian honey. African Journal of Microbiology Research 3 (12): 891 - 896.

SAS (1999). SAS/STAT User's Guide Statistics Version 6. 12 Statistical Analysis System Institute, Cary NC.

Tchoumboue, J., J. Awah-Ndukum, F. A. Fonteh, N. D. Dongock, J. Pinta and A. Mvondoze (2007). Physicochemical and microbiological characteristics of honey from the Sudano-Guinea zones of West Cameroun, Africa. Journal of Biotechnology 6 (7): $908-913$. 
Thrasyvoulou, A. (1997). Heating times for Greek honeys. Melissokomiki Epitherorisi 11 (2): $79-80$.

Tysset, C., C. Durand and Y. P. Tallergio (1970). Contribution to the study of microbial contamination and hygiene of commercial honey. Review Medical Veterinary 146: $1471-1492$.

USDA (2008). National Honey Report. February 12, http://marketnews.usda.gov $/ \mathrm{portal} / \mathrm{fv} /$ honey.

Western, R. J. (2000). The contribution of catalase and other natural products to antibacterial activity of honey. A review. Food Chemistry 71: 235 - 239. www.en.wikipedia.org

White, J. W. (1975b). Composition of honey. In: Honey: A comprehensive survey (ed.) Crane E. Heinemann, London UK pp157 - 206. ISBN 93-8300019-7. 